\title{
GH-releasing peptide-6 overcomes refractoriness of somatotropes to GHRH after feeding
}

\author{
C D McMahon, L T Chapin, R P Radcliff, K J Lookingland ${ }^{1}$ \\ and $\mathbf{H}$ A Tucker
}

Department of Animal Science, Michigan State University, East Lansing, Michigan 48824-1225, USA

${ }^{1}$ Department of Pharmacology and Toxicology, Michigan State University, East Lansing, Michigan 48824-1317, USA

(Requests for offprints should be addressed to C D McMahon who is now at Dairy Science Building, AgResearch, Ruakura Agricultural Centre, P.B. 3123 , Hamilton 2001, New Zealand; Email: chris.mcmahon@agresearch.co.nz)

\begin{abstract}
After a meal, somatotropes are temporarily refractory to growth hormone-releasing hormone $(\mathrm{GHRH})$, the principal hormone that stimulates secretion of growth hormone $(\mathrm{GH})$. Refractoriness is particularly evident when free access to feed is restricted to a 2-h period each day. GH-releasing peptide-6 (GHRP-6), a synthetic peptide, also stimulates secretion of $\mathrm{GH}$ from somatotropes. Because GHRH and GHRP-6 act via different receptors, we hypothesized that GHRP-6 would increase GHRH-induced secretion of GH after feeding. Initially, we determined that intravenous injection of GHRP-6 at 1,3 and $10 \mu \mathrm{g} / \mathrm{kg}$ body weight (BW) stimulated secretion of $\mathrm{GH}$ in a dose-dependent manner. Next, we determined that GHRP-6- and GHRH-induced secretion of GH was lower $1 \mathrm{~h}$ after feeding $(22.5$ and $20 \mathrm{ng} / \mathrm{ml}$ respectively) than $1 \mathrm{~h}$ before feeding $(53.5$ and $64.5 \mathrm{ng} / \mathrm{ml}$ respectively; pooled s.E.M. $=8 \cdot 5$ ). However, a combination of GHRP-6
\end{abstract}

at $3 \mu \mathrm{g} / \mathrm{kg} \mathrm{BW}$ and GHRH at $0 \cdot 2 \mu \mathrm{g} / \mathrm{kg} \mathrm{BW}$ synergistically induced an equal and massive release of $\mathrm{GH}$ before and after feeding that was fivefold greater than GHRHinduced release of $\mathrm{GH}$ after feeding. Furthermore, the combination of GHRP-6 and GHRH synergistically increased release of $\mathrm{GH}$ from somatotropes cultured in vitro. However, it was not clear if GHRP-6 acted only on somatotropes or also acted at the hypothalamus. Therefore, we wanted to determine if GHRP-6 stimulated secretion of GHRH or inhibited secretion of somatostatin, or both. GHRP-6 stimulated secretion of GHRH from bovine hypothalamic slices, but did not alter secretion of somatostatin. We conclude that GHRP-6 acts at the hypothalamus to stimulate secretion of GHRH, and at somatotropes to restore and enhance the responsiveness of somatotropes to GHRH.

Journal of Endocrinology (2001) 170, 235-241

\section{Introduction}

Two neuropeptides principally regulate secretion of growth hormone $(\mathrm{GH})$ : growth hormone-releasing hormone (GHRH) stimulates secretion of GH, and somatostatin inhibits secretion of GH (Tannenbaum \& Ling 1984, Plotsky \& Vale 1985). After feeding, basal and GHRH-induced secretion of GH decrease, but the cause is unknown (Moseley et al. 1988). However, decreased basal and GHRH-induced secretion after feeding are not due to increased activity of somatostatin neurons (McMahon et al. 2000). Therefore, factors other than GHRH and somatostatin must contribute to decreased secretion of $\mathrm{GH}$ after feeding.

Growth hormone-releasing peptide-6 (GHRP-6) is a synthetic peptide that stimulates secretion of $\mathrm{GH}$ and, when combined with GHRH, is either additive or synergistic in stimulating secretion of GH (Cheng et al. 1989, Blake \& Smith 1991, Bowers et al. 1991, Wu et al. 1996).
GHRH and GHRP-6 induce secretion of GH via different receptors and pathways of signal transduction (Mau et al. 1995, Chen et al. 1996, Howard et al. 1996, Wu et al. 1997). Therefore, it is possible that somatotropes are refractory to GHRH, but not GHRP-6 after feeding. In addition, it is not clear if GHRP-6 acts only at somatotropes or if it increases secretion of GHRH and/or decreases secretion of somatostatin to stimulate secretion of $\mathrm{GH}$.

Our objectives were to determine: (1) the minimal effective concentration of GHRP-6 required to stimulate secretion of GH in vivo; (2) if GHRP-6 and GHRH injected together stimulate greater secretion of $\mathrm{GH}$ before and after feeding than either treatment alone; (3) if GHRP-6 and GHRH stimulate greater secretion of $\mathrm{GH}$ from perifused somatotropes than either treatment alone; and (4) if GHRP-6 stimulates secretion of GHRH or inhibits secretion of somatostatin from perifused hypothalamic slices. 


\section{Materials and Methods}

\section{Animals and maintenance}

Eight male Holstein calves born at Michigan State University's Dairy Cattle Teaching and Research Center were castrated at 1 week of age, fed whole milk until 8 weeks of age, then fed a diet containing 18\% crude protein and $19 \cdot 6 \%$ acid detergent fiber (Land O'Lakes, Indianapolis, IN, USA). Steers were moved into individual stalls in rooms (four steers per room) where food was available ad libitum from 1000 to $1200 \mathrm{~h}$ daily and water was available ad libitum. Lights were on for $18 \mathrm{~h}$ each day and temperature was maintained at $20 \pm 1{ }^{\circ} \mathrm{C}$ (mean \pm S.E.M.) in the rooms. At the start of experiments, steers were $24 \pm 1$ weeks old and weighed $171 \pm 8 \mathrm{~kg}$. The Michigan State University All University Committee on Animal Use and Care approved this experiment.

Experiment 1: Dose-response of GHRP-6 on secretion of $\mathrm{GH}$ in vivo

Steers were randomly allocated to two groups of four. A jugular vein of each steer was cannulated $24 \mathrm{~h}$ before the experiment. Patency of each cannula was maintained with sterile $3 \cdot 5 \%$ sodium citrate. Blood samples $(6 \mathrm{ml})$ were collected at 20-min intervals from $20 \mathrm{~min}$ before to $60 \mathrm{~min}$ after i.v. injection of vehicle (sterile water) or GHRP-6 (Bachem, Torrance, CA, USA) at 1, 3 and $10 \mu \mathrm{g} / \mathrm{kg}$ body weight (BW). Blood was allowed to clot at $20^{\circ} \mathrm{C}$ for $2 \mathrm{~h}$, stored at $4{ }^{\circ} \mathrm{C}$ for $22 \mathrm{~h}$ and then centrifuged. Harvested serum was stored at $-20{ }^{\circ} \mathrm{C}$ until required for assay for $\mathrm{GH}$.

Experiment 2: Effect of GHRP-6 and GHRH on secretion of $\mathrm{GH} 1 \mathrm{~h}$ before feeding compared with $1 \mathrm{~h}$ after feeding

Steers were randomly allocated to two groups of four. Each steer was injected i.v. with vehicle, a suboptimal dose of GHRP-6 (3 $\mu \mathrm{g} / \mathrm{kg} \mathrm{BW})$, GHRH ([Leu $\left.{ }^{27}, \mathrm{Hse}^{45}\right]$ bovine $\mathrm{GHRH}_{(1-45)}$ lactone (Pharmacia \& Upjohn, Kalamazoo, MI, USA; $0 \cdot 2 \mu \mathrm{g} / \mathrm{kg} \mathrm{BW;} \mathrm{McMahon} \mathrm{et} \mathrm{al.}$ 2000), and GHRP-6 (3 $\mu \mathrm{g} / \mathrm{kg}$ BW) together with GHRH $(0 \cdot 2 \mu \mathrm{g} / \mathrm{kg} \mathrm{BW})$ in a Latin-square order of treatments. One group was injected at $0900 \mathrm{~h}$ and the other group was injected at $1300 \mathrm{~h}$ on each treatment day. One to two days separated each replicate in the Latin square for each group.

Experiment 3: Effect of GHRP-6 and GHRH on secretion of $\mathrm{GH}$ from perifused dispersed anterior pituitary cells

Pituitaries were collected from a local abattoir (Bellingar Packing, Ashley, MI, USA) and isolated anterior pituitary cells were prepared and perifused as previously described (Gaynor et al. 1996). Anterior pituitary cells
( $n=8$ perifusion chambers per treatment) were treated with vehicle (minimal essential medium alpha, MEM $\alpha$ ), GHRP-6 $\left(10^{-8} \mathrm{M}\right)$, GHRH $\left(10^{-8} \mathrm{M}\right)$, GHRP-6 $\left(10^{-8} \mathrm{M}\right)$ together with GHRH $\left(10^{-8} \mathrm{M}\right)$, a GHRH receptor antagonist (GHRHra) ([Ac-Tyr 1, D-Arg $\left.{ }_{2}\right]-$ GHRH $_{(1-29)} ; 10^{-6} \mathrm{M}$; Bachem), or GHRHra $\left(10^{-6} \mathrm{M}\right)$ together with GHRP-6 $\left(10^{-8} \mathrm{M}\right)$.

\section{Experiment 4: Effect of GHRP-6 on secretion of GHRH and somatostatin from perifused hypothalamic slices}

Bovine hypothalami were collected from a local abattoir (Bellingar Packing) within 10-15 min of death, bisected mid-sagittally and a single $1-\mathrm{mm}$ thick slice was taken from and including the third ventricle from each hemihypothalamus using custom built Plexiglass tissue slicer as described elsewhere (McMahon et al. 2001). Each sagittal hemi-hypothalamic slice had its hypothalamic stalk attached.

Single slices were placed in barrels of $5 \mathrm{ml}$ syringes, which served as perifusion chambers containing MEM $\alpha$ saturated in 100\% oxygen (West et al. 1997a). These perifusion chambers were transported to the laboratory at $4{ }^{\circ} \mathrm{C}$.

In the laboratory, chambers were connected to a peristaltic pump and perifused at $37^{\circ} \mathrm{C}$ with MEM $\alpha$ saturated with $95 \% \mathrm{O}_{2}-5 \% \mathrm{CO}_{2}$. Perifusion was performed as previously described (West et al. 1997a). Slices $(n=6$ per treatment) were treated with vehicle (MEM $\alpha)$, or GHRP-6 for $20 \mathrm{~min}$ at $10^{-10} \mathrm{M}, 10^{-8} \mathrm{M}$, and $10^{-6} \mathrm{M}$ by turning 3-way stopcocks to gain access to treatments held in $50 \mathrm{ml}$ siliconized conical tubes.

Collected fractions were stored at $-20{ }^{\circ} \mathrm{C}$ until required for assay for $\mathrm{GHRH}$ and somatostatin.

\section{Growth hormone assay}

GH was measured using a radioimmunoassay (Gaynor et al. 1995) in which the intra-assay and interassay coefficients of variation were $12 \cdot 1$ and $14.9 \%$ respectively.

\section{GHRH and somatostatin assays}

GHRH and somatostatin were measured using radioimmunoassays as previously described (McMahon et al. 2001). Intra-assay coefficients of variation were $4 \cdot 4 \%$ and $7 \cdot 9 \%$ respectively.

\section{Statistical analyses}

Net areas under GH, GHRH and somatostatin curves were calculated as follows. Total areas under the curves were calculated using the trapezoid method after injection of vehicle or treatment, from 0 to $40 \mathrm{~min}$ for Experiments 1 and 2, from 20 to $140 \mathrm{~min}$ for Experiment 3 and from 40 to $160 \mathrm{~min}$ for Experiment 4 . The area of the rectangle 
calculated from mean concentrations of GH, GHRH and somatostatin at time 0 and projected to $40 \mathrm{~min}$ for Experiments 1 and 2 or from 40 (sample before treatment) to $160 \mathrm{~min}$ for Experiment 3 and from 20 (sample before treatment) to $140 \mathrm{~min}$ for Experiment 4 were used to estimate baseline, which was subtracted from the total areas under the curve to yield net areas in each experiment.

Net GH peak was calculated as the greatest concentration from 0 to $60 \mathrm{~min}$ minus the concentration at $0 \mathrm{~min}$.

Data were log-transformed where appropriate, to stabilize the variance. Experiments 1, 3 and 4 were subjected to ANOVA using the generalized linear models procedure in SAS (1990) with factors of treatment (all experiments), replicate (first or second replicate on the same day; Experiments 3 and 4), and period (successive experiments over different days; Experiment 4) included in the model statement. Data in Experiment 2 were subjected to ANOVA using the Mixed Procedure in SAS with factors of treatment, time (before or after feeding), replicate of the Latin square (replicate), replicate $\times$ treatment and treatment $\times$ time as fixed variables, and animal nested with time as a random variable in the model statement. Differences between means, when the $F$-test was significant $(P<0 \cdot 05)$, were evaluated using the PDIFF option of SAS and in Experiment 3 adjusted for multiple comparisons using the method of Tukey (Sokal \& Rohlf 1995). Data are reported as least squares means \pm pooled standard error of the mean (S.E.M.).

\section{Results}

Experiment 1: Dose-response of GHRP-6 on secretion of $\mathrm{GH}$ in vivo

GHRP-6 stimulated secretion of GH in a dose-dependent manner compared with vehicle-injected controls (Fig. 1).

Experiment 2: Effect of GHRP-6 and GHRH on secretion of $\mathrm{GH} 1 \mathrm{~h}$ before feeding compared with $1 \mathrm{~h}$ after feeding

Mean basal concentrations of $\mathrm{GH}$ were greater $(P<0 \cdot 01)$ before $(5 \cdot 2 \pm 0 \cdot 7 \mathrm{ng} / \mathrm{ml})$ than after feeding $(1 \cdot 4 \pm 0 \cdot 8 \mathrm{ng} / \mathrm{ml})$.

As shown in Fig. 2, the net area under the GH curve was greater $(P<0.05)$ for GHRH given before feeding $(1207 \mathrm{ng} / \mathrm{ml}$ per $\mathrm{min} ; 0900 \mathrm{~h})$ than for $\mathrm{GHRH}$ given after feeding $(422 \mathrm{ng} / \mathrm{ml}$ per $\mathrm{min} ; 1300 \mathrm{~h}$ ) (pooled S.E.M. $=210)$. GHRP-6 induced greater $(P<0 \cdot 05)$ net $\mathrm{GH}$ peak before $(53.5 \mathrm{ng} / \mathrm{ml})$ than after feeding $(22.5 \mathrm{ng} / \mathrm{ml})$ (pooled S.E.M. $=8 \cdot 5$ ). However, net areas under the GH curves were not different $(P=0 \cdot 44)$ for GHRP-6 given before $(713 \mathrm{ng} / \mathrm{ml}$ per min) or after feeding $(472 \mathrm{ng} / \mathrm{ml}$ per $\min$ ) (pooled s.E.M. $=210$ ). GHRH and GHRP-6 given together stimulated the greatest area under the $\mathrm{GH}$

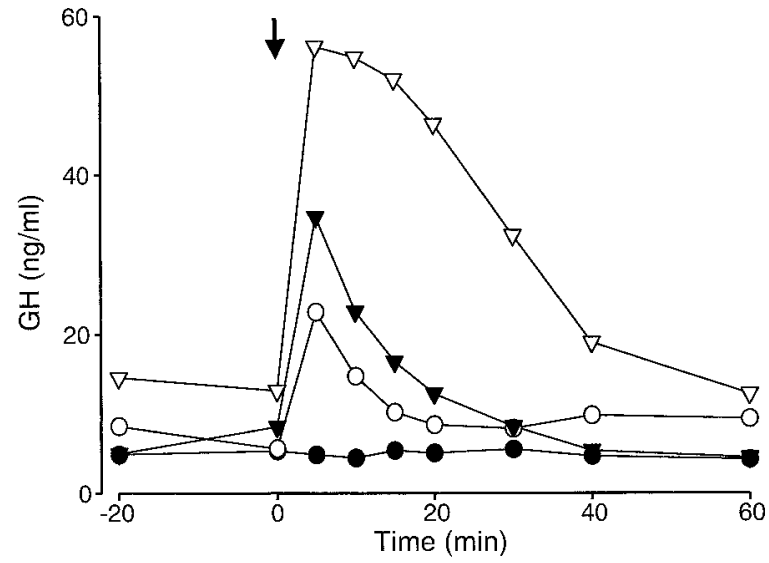

Figure 1 Effect of i.v. injection of vehicle (sterile water, 0 ) and GHRP- 6 at $1 \mu \mathrm{g} / \mathrm{kg}(\bigcirc), 3 \mu \mathrm{g} / \mathrm{kg}(\boldsymbol{\nabla})$, and $10 \mu \mathrm{g} / \mathrm{kg}$ body weight $(\nabla)$ to Holstein steers on concentrations of $\mathrm{GH}$ in serum. Arrow indicates time of i.v. injection. Pooled S.E.M. $=11 \cdot 2 \mathrm{ng} / \mathrm{ml}$.

curve $(2315 \mathrm{ng} / \mathrm{ml}$ per $\mathrm{min})$ compared with either GHRH (815 ng/ml per min) or GHRP-6 alone (592 ng/ $\mathrm{ml}$ per $\mathrm{min}$ ) (pooled S.E.M. $=148 ; P<0 \cdot 001)$. There were no differences between net $\mathrm{GH}$ peaks $(P=0 \cdot 23)$ or net
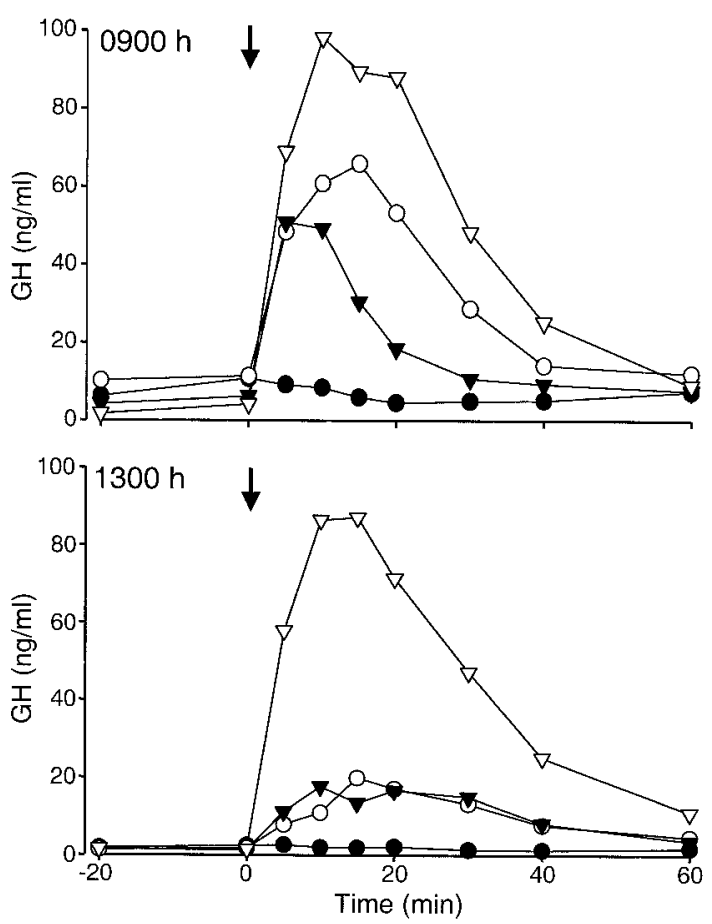

Figure 2 Effect of i.v. injection of vehicle (sterile water, $\mathbf{0}$ ), GHRH $(0 \cdot 2 \mu \mathrm{g} / \mathrm{kg}, \bigcirc)$, GHRP-6 $(3 \mu \mathrm{g} / \mathrm{kg}, \boldsymbol{\nabla})$ and GHRH together with GHRP-6 $(\nabla), 1 \mathrm{~h}$ before feeding $(0900 \mathrm{~h})$, or $1 \mathrm{~h}$ after feeding $(1300 \mathrm{~h})$, on concentrations of $\mathrm{GH}$ in serum in Holstein steers. Arrows indicate time of i.v. injection. Pooled S.E.M. $=13 \mathrm{ng} / \mathrm{ml}$. 


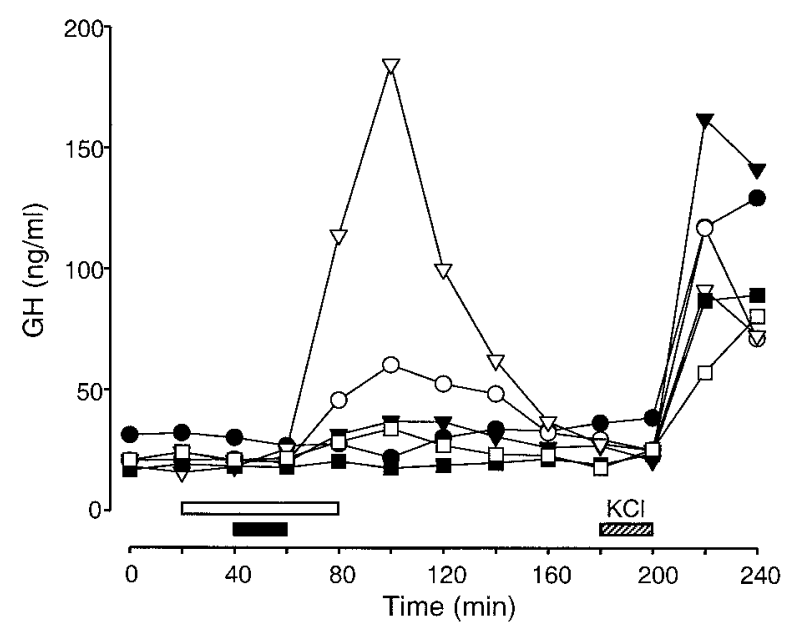

Figure 3 Effect of vehicle (MEM $\alpha, 0)$, GHRH $\left(10^{-8} \mathrm{M}, \bigcirc\right)$, GHRP-6 $\left(10^{-8} \mathrm{M}, \mathbf{\nabla}\right)$, GHRH together with GHRP-6 $\left(10^{-8} \mathrm{M}\right.$ each, $\nabla), \mathrm{GHRH}$ receptor antagonist (GHRHra; $\left.10^{-6} \mathrm{M}, \mathbf{\square}\right)$ and GHRHra with GHRP-6 ( $\square$ ) on concentrations of GH in perifusates from dispersed bovine anterior pituitary cells. Solid bar indicates when vehicle, GHRH, GHRP-6, GHRH with GHRP-6, and GHRHra were perifused for $20 \mathrm{~min}$. Open bar indicates 60-min period during which GHRHra $\left(10^{-6} \mathrm{M}\right)$ was perifused alone from 21 to $40 \mathrm{~min}$, together with GHRP-6 $\left(10^{-8} \mathrm{M}\right)$ from 41 to $60 \mathrm{~min}$, and alone from 61 to $80 \mathrm{~min}$. Potassium chloride $(60 \mathrm{mM})$ was perifused between 181 and 200 min (cross-hatched bar) to stimulate secretion of $\mathrm{GH}$, to verify that somatotropes were viable. Pooled S.E.M. $=20 \cdot 2 \mathrm{ng} / \mathrm{ml}$.

areas under the GH curve $(P=0.59)$ for combined treatment of GHRH with GHRP-6 before and after feeding.

Experiment 3: Effect of GHRP-6 and GHRH on secretion of $\mathrm{GH}$ from perifused dispersed anterior pituitary cells

GHRH increased net area under the GH curve (3392 ng/ $\mathrm{ml}$ per min) compared with controls $(276 \mathrm{ng} / \mathrm{ml}$ per $\mathrm{min})$ (pooled s.E.M. $=847 ; \quad P<0 \cdot 05 ; \quad$ Fig. 3). In contrast, GHRP-6 did not alter net GH peak $(P=0 \cdot 6)$ or net area under the GH curve $(P=0 \cdot 7)$ compared with controls. Combined treatment of GHRH with GHRP-6 stimulated a greater area under the GH curve $(9113 \mathrm{ng} / \mathrm{ml}$ per min) compared with either GHRH $(P<0 \cdot 01)$ or controls $(P<0 \cdot 001)$. The net areas under GH curves were not different among GHRHra-treated (404 ng/ml per min), GHRP-6 and GHRHra-treated (617 ng/ml per min) and control-treated somatotropes $(276 \mathrm{ng} / \mathrm{ml}$ per min; pooled S.E.M. $=847 ; P=1 \cdot 0)$.

Experiment 4: Effect of GHRP-6 on secretion of GHRH and somatostatin from perifused hypothalamic slices

Net area under the GHRH curve was greater for hypothalamic slices treated with GHRP-6 at $10^{-6} \mathrm{M}$ (4773 $\mathrm{ng} / \mathrm{ml}$ per min) than for controls (1704 $\mathrm{ng} / \mathrm{ml}$ per
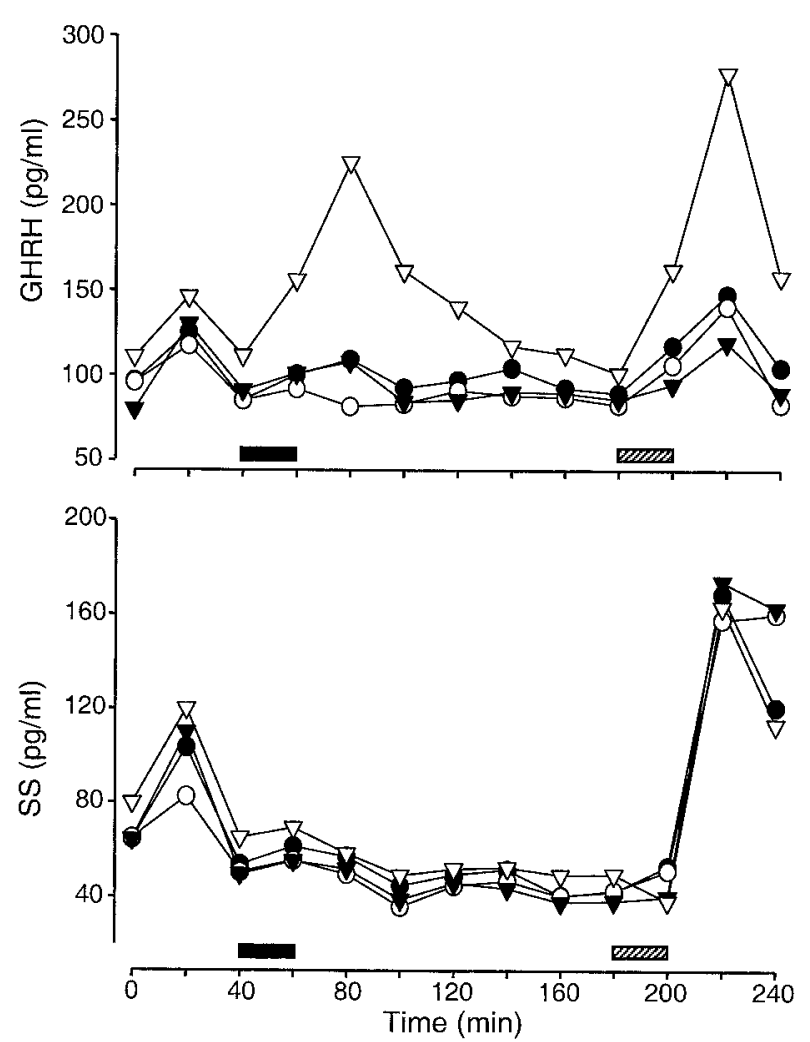

Figure 4 Effect of vehicle (MEM $\alpha, \mathbf{0})$, GHRP- 6 at $10^{-10} \mathrm{M}(\bigcirc)$, $10^{-8} \mathrm{M}(\boldsymbol{\nabla})$, or $10^{-6} \mathrm{M}(\nabla)$ on concentrations of GHRH (top) and somatostatin (SS; bottom) in perifusates from $1 \mathrm{~mm}$ slices of bovine hemi-hypothalami. Solid bar indicates when vehicle or GHRP-6 were perifused for $20 \mathrm{~min}$. Cross-hatched bar indicates a 20-min period when $60 \mathrm{mM} \mathrm{KCl}$ was perifused to stimulate secretion of $\mathrm{GHRH}$ and somatostatin, to verify that tissues were viable. Pooled S.E.M. values are $19 \cdot 2 \mathrm{pg} / \mathrm{ml}$ for $\mathrm{GHRH}$ and $19 \cdot 5 \mathrm{pg} / \mathrm{ml}$ for somatostatin.

min, pooled S.E.M. $=819, P=0 \cdot 07$; Fig. 4$).$ GHRP-6 did not alter concentrations of somatostatin compared with controls $(P=0 \cdot 42)$.

\section{Discussion}

Decreased basal and GHRH-induced secretion of GH after feeding is a common phenomenon in ruminants (Moseley et al. 1988, Plouzek et al. 1988, Trenkle 1989). Furthermore, reduced secretion of $\mathrm{GH}$ from somatotropes after feeding is not limited to that induced by GHRH, because $\alpha_{2}$-adrenergic-induced secretion of $\mathrm{GH}$ is also reduced after feeding (Gaynor et al. 1993). How and why somatotropes become refractory to GHRH after feeding is not known. However, given that the combination of GHRH with GHRP-6 induced rapid and massive release of GH before and after feeding, it seems likely that releasable pools of $\mathrm{GH}$ are not reduced and that receptors 
to GHRH and GHRP-6 are not down-regulated. Rather, it is likely that there is a change in receptor signaling after feeding that is overcome by stimulating GHRH and GHRP-6 receptors together, while remaining refractory to either peptide alone.

Somatostatin is the principal hormone inhibiting secretion of GH and it is reasonable to expect increased activity of somatostatin neurons after feeding. However, previous investigations in our laboratory have demonstrated that reduced basal and GHRH-induced secretion of GH are not the result of increased activity (determined using the presence of Fos as an immunoreactive marker of neuronal activity) of somatostatin neurons, decreased activity of GHRH neurons, or both (McMahon et al. 2000). Therefore, factors other than somatostatin bestow on somatotropes a refractoriness to GHRH after feeding, and GHRP-6 overcomes such factors for at least $1 \mathrm{~h}$ after feeding.

GHRP-6 does not act solely at somatotropes, and the brain is considered to be a major target. The present data demonstrate that GHRP-6 stimulates secretion of GHRH without altering secretion of somatostatin in vitro. Our data extend those of others who have reported that GHRP-6 stimulates secretion of GHRH and increases the frequency of pulses of GHRH without altering secretion of somatostatin in vivo (Guillaume et al. 1994, Fletcher et al. 1996). In addition, GHRP-6 increases expression of c-fos, an immediate-early gene, in the arcuate nucleus, where GHRH neurons are located (Merchenthaler et al. 1984), suggesting direct action of GHRP-6 on GHRH neurons (Dickson et al. 1995). In contrast, Fairhall et al. (1995) reported that GHRP-6 inhibited secretion of somatostatin, thereby enhancing GHRH-induced secretion of GH. Furthermore, somatostatin was found to inhibit GHRP6-induced secretion of GH in vitro (Cheng et al. 1989, Wu et al. 1996). Therefore, although the current study and that of Guillaume et al. (1994) do not support a decrease in secretion of somatostatin into hypophysial-portal blood, this does not discount the possibility that GHRP-6 blocks the somatostatin inhibition of GHRH neurons in the arcuate nucleus (Fairhall et al. 1995). It is possible, as Fairhall et al. (1995) suggested, that GHRP-6 blocks somatostatin receptors, which, in turn, enables secretion of GHRH. Blockade of somatostatin receptors on GHRH neurons, rather than directly stimulating GHRH neurons does not account for increased expression of $c$-fos in the arcuate nucleus unless GHRP-6 activates neurons other than GHRH, which, in turn, stimulate secretion of GHRH. This concept is not without foundation as it is believed that GHRP-6 acts in conjunction with another or other neurotransmitters that are, as yet, unknown (termed U-factor), to stimulate secretion of GH (Bowers 1999).

One disadvantage of perifusing slices of hypothalami is that pharmacological doses are often required to induce secretion of GHRH and somatostatin (West et al. 1997a,b).
Indeed, in the current study $10^{-6} \mathrm{M}$ GRHP-6 induced secretion of GHRH, whereas lower molar concentrations had no effect. Slices of hypothalami perifused in the current study were $1 \mathrm{~mm}$ thick and, therefore, receptors for GHRP-6, somatostatin and GHRH may not be as readily accessible as they would be, for example, on dispersed somatotrope cells. Therefore, after diffusing into tissue, $10^{-6} \mathrm{M}$ GRHP-6 in media may be diluted to a lower molar concentration at the receptors.

A clear role for GHRP-6 in regulating the secretion of $\mathrm{GH}$ has yet to be established. The current data show that GHRP-6 stimulates secretion of GHRH, but GHRP-6 also has independent and direct actions on somatotropes. For example, GHRP-6 stimulated secretion of GH from somatotropes in vitro (Wu et al. 1996) and stimulated secretion of GH in vivo after hypophysial-portal vessels those transporting GHRH to somatotropes - had been removed (Fletcher et al. 1994). Yet, it is not clear if GHRP-6 stimulates secretion of GH via specific receptors only or also acts via GHRH receptors on somatotropes. For example, blockade of GHRH receptors reduced GHRP6-induced secretion of GH in vivo and blocked GHRP-2 (another GHRP)-induced secretion of GH in vitro (Wu et al. 1994, Pandya et al. 1998). Receptors for GHRP-6-like peptide are located in the anterior pituitary gland and hypothalamus, which lends support to their having direct actions in the hypothalamus and anterior pituitary gland (Codd et al. 1989, Sethumadhavan et al. 1991, Howard et al. 1996). In the present investigation, GHRP-6 did not stimulate secretion of $\mathrm{GH}$ in vitro and, therefore, blockade of GHRH receptors was also without effect. Thus the present data support the concept of synergy between GHRP-6 and GHRH to stimulate secretion of GH in vitro (Cheng et al. 1989). These data contrast with other findings in which GHRP-6 was additive, rather than synergistic, with GHRH to stimulate secretion of $\mathrm{GH}$ in vitro (Blake \& Smith 1991, Bowers et al. 1991, Wu et al. 1996, Bowers 1999).

In the current study, combined treatments of GHRP-6 and GHRH were additive before feeding, but synergistic after feeding. Typically, in vivo, GHRP-6 and GHRH are synergistic, especially when sub-maximal doses of GHRP-6 are used (Bowers 1999). However, not only does meal-feeding synchronize secretion of $\mathrm{GH}$, but also somatotropes are more responsive to either GHRH or GHRP-6 alone before than after feeding. Importantly, the combined treatments of GHRP-6 and GHRH given before and after feeding were equal and massive in magnitude. We are unaware of any treatment able to stimulate greater secretion of $\mathrm{GH}$ in cattle and believe we achieved maximal secretion of the available pools of $\mathrm{GH}$. Therefore, although sub-maximal doses of GHRP-6 combined with GHRH typically elicit synergistic secretion of GH in vivo (Bowers 1999), we speculate that the releasable pools of $\mathrm{GH}$ are depleted before synergistic actions are observed before feeding. 
In conclusion, GHRP-6 restores and enhances GHRHinduced secretion of $\mathrm{GH}$ after feeding via independently increasing the secretion of GHRH from the hypothalamus and acting in synergy with GHRH at somatotropes.

\section{Acknowledgements}

We are grateful to the staff at the Dairy Cattle Teaching and Research Center at Michigan State University for animal care and maintenance, and to the staff at Bellingar Packing, Ashley, MI, USA for providing bovine pituitary glands and hypothalami. Gifts of $\left[\mathrm{Leu}^{27}, \mathrm{Hse}^{45}\right]$ $\mathrm{bGHRH}_{(1-45)}$ lactone and rabbit anti-bGHRH from Pharmacia \& Upjohn, Kalamazoo, MI, USA, and antiserum to ovine GH (rabbit anti-oGH-2) from the National Hormone and Pituitary Program, Rockville, MD, USA are greatly appreciated. The United States Department of Agriculture National Research Initiative Grant 9603287 supported this research.

\section{References}

Blake AD \& Smith RG 1991 Desensitization studies using perifused rat pituitary cells show that growth hormone-releasing hormone and His-D-Trp-Ala-Trp-D-Phe-Lys- $\mathrm{NH}_{2}$ stimulate growth hormone release through distinct receptor sites. Journal of Endocrinology 129 $11-19$.

Bowers CY 1999 Growth hormone-releasing peptides. In Handbook of Physiology, Section 7: The endocrine system, Volume V: Hormonal control of growth. pp 267-297. Eds JL Kostyo \& HM Goodman. Oxford: Oxford University Press.

Bowers CY, Sartor AO, Reynolds GA \& Badger TM 1991 On the action of the growth hormone-releasing hexapeptide, GHRP. Endocrinology 128 2027-2035.

Chen C, Wu D \& Clarke IJ 1996 Signal transduction systems employed by synthetic GH-releasing peptides in somatotrophs. Journal of Endocrinology 148 381-386.

Cheng K, Chan WW, Barreto A Jr, Convey EM \& Smith RG 1989 The synergistic effects of His-D-Trp-Ala-Trp-D-Phe-Lys- $\mathrm{NH}_{2}$ on growth hormone $(\mathrm{GH})$-releasing factor-stimulated $\mathrm{GH}$ release and intracellular adenosine $3^{\prime}, 5^{\prime}$-monophosphate accumulation in rat primary pituitary cell culture. Endocrinology 124 2791-2798.

Codd EE, Shu AYL \& Walker RF 1989 Binding of a growth hormone releasing hexapeptide to specific hypothalamic and pituitary binding sites. Neuropharmacology 28 1139-1144.

Dickson SL, Leng G, Dyball REJ \& Smith RG 1995 Central actions of peptide and non-peptide growth hormone secretagogues in the rat. Neuroendocrinology 61 36-43.

Fairhall KM, Mynett A, Robinson ICAF 1995 Central effects of growth hormone-releasing hexapeptide (GHRP-6) on growth hormone release are inhibited by central somatostatin action. Journal of Endocrinology 144 555-560.

Fletcher TP, Thomas GB, Willoughby JO \& Clarke IJ 1994 Constitutive growth hormone secretion in sheep after hypothalamopituitary disconnection and the direct in vivo pituitary effect of growth hormone releasing peptide 6. Neuroendocrinology 60 76-86.

Fletcher TP, Thomas GB \& Clarke IJ 1996 Growth hormonereleasing hormone and somatostatin concentrations in the hypophysial portal blood of conscious sheep during the infusion of growth hormone-releasing peptide-6. Domestic Animal Endocrinology $13251-258$
Gaynor PJ, Chapin LT, Lookingland KJ \& Tucker HA 1993 $\alpha_{2}$-Adrenergic receptor-mediated regulation of growth hormone secretion in meal-fed Holstein steers. Proceedings of the Society for Experimental Biology and Medicine 204 318-322.

Gaynor PJ, Lookingland KJ \& Tucker HA 1995 5-Hydroxytryptaminergic receptor-stimulated growth hormone secretion occurs independently of changes in peripheral somatostatin concentration. Proceedings of the Society for Experimental Biology and Medicine 209 79-85.

Gaynor PJ, Simmons CR, Lookingland KJ \& Tucker HA 1996 5-Hydroxytryptaminergic receptor-mediated regulation of growth hormone secretion in Holstein steers occurs via $\alpha_{2}$-adrenergicdependent and -independent mechanisms. Proceedings of the Society for Experimental Biology and Medicine 212 355-361.

Guillaume V, Magnan E, Cataldi M, Dutour A, Sauze N, Renard M, Razafindraibe H, Conte-Devolx B, Deghenghi R, Lenaerts V \& Oliver C 1994 Growth hormone (GH)-releasing hormone secretion is stimulated by a new GH-releasing hexapeptide in sheep. Endocrinology 135 1073-1076.

Howard AD, Feighner SD, Cully DF, Arena JP, Liberator PA, Rosenblum CI, Hamelin M, Hreniuk DL, Palyha OC, Anderson J, Paress PS, Diaz C, Chou M, Liu KK, McKee KK, Pong S-S, Chaung L-Y, Elbrecht A, Dashkevicz M, Heavens R, Rigby M, Sirinathsinghji DJS, Dean DC, Melillo DG, Patchett AA, Nargund R, Griffin PR, DeMartino JA, Gupta SK, Schaeffer JM, Smith RG \& Van der Ploeg LHT 1996 A receptor in pituitary and hypothalamus that functions in growth hormone release. Science $\mathbf{2 7 3}$ 974-977.

McMahon CD, Chapin LT, Lookingland KJ, Radcliff RP \& Tucker HA 2000 Feeding reduces activity of growth hormone-releasing hormone and somatostatin neurons. Proceedings of the Society for Experimental Biology and Medicine 223 210-217.

McMahon CD, Chapin LT, Radcliff RP, Lookingland KJ \& Tucker HA 2001 Somatostatin inhibits alpha-2-adrenergic-induced secretion of growth hormone-releasing hormone. Neuroendocrinology 73 (In Press).

Mau SE, Witt MR, Bjerrum OJ, Saermark T \& Vilhardt H 1995 Growth hormone releasing hexapeptide (GHRP-6) activates the inositol $(1,4,5)$-triphosphate/diacylglycerol pathway in rat anterior pituitary cells. Journal of Receptor and Signal Transduction Research 15 311-323.

Merchenthaler I, Vigh S, Schally AV, Petrusz P 1984 Immunocytochemical localization of growth hormone-releasing factor in the rat hypothalamus. Endocrinology 114 1082-1085.

Moseley WM, Alaniz GR, Claflin WH \& Krabill LF 1988 Food intake alters the serum growth hormone response to bovine growth hormone-releasing factor in meal-fed Holstein steers. Journal of Endocrinology 117 253-259.

Pandya N, DeMott-Friberg R, Bowers CY, Barkan AL \& Jaffe CA 1998 Growth hormone $(\mathrm{GH})$-releasing peptide-6 requires endogenous hypothalamic GH-releasing hormone for maximal GH stimulation. Journal of Clinical Endocrinology and Metabolism $\mathbf{8 3}$ 1186-1189.

Plotsky PM \& Vale W 1985 Patterns of growth hormone-releasing factor and somatostatin secretion into the hypophysial-portal circulation of the rat. Science 230 461-463.

Plouzek CA, Molina JR, Hard DL, Vale WW, Rivier J, Trenkle A \& Anderson LL 1988 Effects of growth hormone-releasing factor and somatostatin on growth hormone secretion in hypophysial stalk-transected beef calves. Proceedings of the Society of Experimental Biology and Medicine 189 158-167.

SAS 1990 SAS/STAT User's Guide, Version 6, edn 4, pp 891-996. Cary, NC: SAS Institute Inc.

Sethumadhavan K, Veeraragavan K \& Bowers CY 1991 Demonstration and characterization of the specific binding of growth hormone-releasing peptide to rat anterior pituitary and hypothalamic membranes. Biochemical and Biophysical Research Communications 178 31-37. 
Sokal RR \& Rohlf FJ 1995 Biometry: the Principles and Practice of Statistics in Biological Research, edn 3, pp 392-450. New York: WH Freeman and Company.

Tannenbaum GS \& Ling N 1984 The interrelationship of growth hormone $(\mathrm{GH})$-releasing factor and somatostatin in generation of the ultradian rhythm of GH secretion. Endocrinology 115 1952-1957.

Trenkle A 1989 Influence of feeding on growth hormone secretion and response to growth hormone-releasing factor in sheep. Journal of Nutrition 119 61-65.

West CR, Gaynor PJ, Lookingland KJ \& Tucker HA 1997 a Regulation of growth hormone-releasing hormone and somatostatin from perifused, bovine hypothalamic slices. I. $\alpha_{2}$-Adrenergic receptor regulation. Domestic Animal Endocrinology 14 334-348.

West CR, Lookingland KJ \& Tucker HA 1997b Regulation of growth hormone-releasing hormone and somatostatin from perifused, bovine hypothalamic slices. II. Dopamine receptor regulation. Domestic Animal Endocrinology 14 349-357.
Wu D, Chen C, Katoh K, Zhang J \& Clarke IJ 1994 The effect of GH-releasing peptide-2 (GHRP-2 or KP 102) on GH secretion from primary cultured ovine pituitary cells can be abolished by a specific GH-releasing factor (GRF) receptor antagonist. Journal of Endocrinology 140 R9-R13.

Wu D, Chen C, Zhang J, Bowers CY \& Clarke IJ 1996 The effects of GH-releasing peptide-6 (GHRP-6) and GHRP-2 on intracellular adenosine $3^{\prime}, 5^{\prime}$-monophosphate (cAMP) levels and GH secretion in ovine and rat somatotrophs. Journal of Endocrinology 148 197-205.

Wu D, Clarke IJ \& Chen C 1997 The role of protein kinase C in $\mathrm{GH}$ secretion induced by GH-releasing factor and GH-releasing peptides in cultured ovine somatotrophs. Journal of Endocrinology 154 219-230.

Received in final form 1 March 2001

Accepted 26 March 2001 